University of Louisville

ThinkIR: The University of Louisville's Institutional Repository

$12-2013$

\title{
Talking across borders : information and communication technology use among Iraqi refugees in Amman, Jordan, and Louisville, Kentucky.
}

Irene Levy

University of Louisville

Follow this and additional works at: https://ir.library.louisville.edu/honors

Part of the Linguistic Anthropology Commons

\section{Recommended Citation}

Levy, Irene, "Talking across borders : information and communication technology use among Iraqi refugees in Amman, Jordan, and Louisville, Kentucky." (2013). College of Arts \& Sciences Senior Honors Theses. Paper 97.

http://doi.org/10.18297/honors/97

This Senior Honors Thesis is brought to you for free and open access by the College of Arts \& Sciences at ThinkIR: The University of Louisville's Institutional Repository. It has been accepted for inclusion in College of Arts \& Sciences Senior Honors Theses by an authorized administrator of ThinkIR: The University of Louisville's Institutional Repository. This title appears here courtesy of the author, who has retained all other copyrights. For more information, please contact thinkir@louisville.edu. 
Talking Across Borders:

Information and Communication Technology Use Among Iraqi Refugees in Amman, Jordan and Louisville, Kentucky

By

Irene Levy

Submitted in partial fulfillment of the requirements

for Graduation summa cum laude

and

for Graduation with Honors from the Department of Anthropology

University of Louisville

December, 2013 


\begin{abstract}
A series of interviews conducted in Amman, Jordan and Louisville, Kentucky posed the following questions: "How is information and communication technology (ICT) use affecting interpersonal communication patterns within the displaced Iraqi community in the US and Jordan?" and "What are the factors that limit the proliferation of the internet as a communication tool in that community?" Participants were individuals with legal refugee status and Iraqi nationality who left Iraq after the beginning of the 2003 Iraq War. Eight interviews were conducted in Louisville during the summer of 2012 and twelve were conducted in Amman during November 2012. Participants were asked demographic questions, as well as questions about their use of mobile phones and the internet. Based on these interviews and a survey of information collected on mobile phone and internet access in Jordan and Iraq, the researcher concluded that Iraqi refugees primarily utilize ICTs to communicate with relatives abroad. Younger participants in both Jordan and the US use ICTs to communicate with friends more often than older individuals. Participants in Jordan were more likely to call relatives in Iraq instead of using the internet than participants in the US. Interviewees in the US used smart phones, while few in Jordan did. Access issues for Iraqis in Jordan included cost and security concerns. Iraqis in the US had few access concerns. Differences between the two groups can be attributed to resource differences, as most of the participants in the US came directly from Iraq and came from well-off families and those in Jordan had exhausted their savings while waiting for resettlement. This study expands the information available on the subject of refugees' transnational communication patterns and could be helpful to aid and resettlement organizations in the future.
\end{abstract}




\section{Acknowledgements}

I would like to thank my adviser, Dr. Haitham al-Zou'bi, for all of his vital assistance with arranging interviews and revising questions. Thanks to all of the staff at the East Amman Association and the Noor al-Hussein Foundation for their cooperation and time. I would also like to thank Dr. Raed al-Tabani and Dr. Ashraf al-Quds who assisted me throughout my research in Jordan as well as all of the other SIT Jordan staff for supporting me throughout my transition from Tunisia to Jordan. I should also recognize the Benjamin A. Gilman International Scholarship and the University of Louisville World Scholars Program for their generous financial support of my semester abroad.

For help with my work in the US, I would like to thank my mentor, Dr. Julie Peteet, the staff and faculty of the Department of Anthropology, and the Summer Research Opportunity Program for their generous funding and support. Additionally, I would like to thank the staff and clients of Kentucky Refugee Ministries for their time and patience. 


\section{Introduction}

Kentucky Refugee Ministries' (KRM) halls are packed during the fifteen minute break halfway through daily English as a second language classes. Crowds of refugees of various nationalities congregate outside as well, smoking and chatting. I stand with a group of young Iraqi men on the building's porch. Every once in a while, one of them whips out his smart phone to type a text. The man I'm talking to struggles to remember an English word. He pulls an iPhone out of his pocket, opens Google Translate, and types in a word, taqālìd; the program quickly replies "traditions".

Advances in technology have significantly changed the way that humans communicate across international borders over the past twenty years. More and more people across the world are accessing computers and the Internet. Although poor infrastructure and censorship severely limited internet access in Iraq in the recent past, since the end of sanctions and the start of rebuilding efforts after the initial phases of the 2003 US invasion, internet access has proliferated. In addition, access is far more common in many of the countries where Iraqi refugees commonly seek asylum, including Egypt, Jordan, Lebanon, Syria, and Turkey, and the regions where Iraqis have often been resettled, such as Europe, Australia, and the US. The sudden introduction of such a new and revolutionary mode of communication is bound to have effects on the lives of displaced Iraqis.

This study will explore two primary research questions: how is information and communication technology (ICT) use affecting interpersonal communication patterns within the displaced Iraqi community in the US and Jordan and what are the factors that limit the proliferation of the internet as a communication tool in that community? Based on the evidence gathered over the course of this study, it appears that Iraqi refugees in the US and Jordan use 
ICTs to strengthen their social networks in Iraq and abroad and cope with the difficulties associated with displacement. Iraqi's strong value for family ties seems to overcome geographic divides, indicating that Iraqi refugees' social experience may support the "transmigrant" model of transnational migration. However, socioeconomic status and education are highly correlated with ability to access the internet.

Evidence to support this assertion is drawn from interviews with Iraqi refugees: a set of eight conducted in summer 2012 in Louisville and a set of twelve conducted in fall 2012 in Amman. All interview participants were Iraqi adults claiming refugee status who had fled Iraq after the US invasion in 2003. Interviews were semi-structured and consisted of a series of predetermined questions as well as additional questions for clarification purposes. Questions were aimed at outlining each participant's demographic information, their trajectory starting in their home in Iraq, and their experiences with communications technology.

My definition of "refugee" for the purpose of this study will be based on the legal definition of a refugee as established by the United Nations High Commissioner on Refugees (UNHCR) in the 1951 Convention Relating to the Status of Refugees and modified by the 1967 Protocol Relating to the Status of Refugees. The 1951 Convention states that a refugee is a person who

"owing to wellfounded fear of being persecuted for reasons of race, religion, nationality, membership of a particular social group or political opinion, is outside the country of his nationality and is unable or, owing to such fear, is unwilling to avail himself of the protection of that country; or who, not having a nationality and being outside the country of his former habitual residence as a result of such events, is unable or, owing to such fear, is unwilling to return to it" [UNHCR 2010 [1951, 1967]: 14]. ${ }^{1}$

The popular phrase "information and communication technologies" is abbreviated here

1While the 1951 Convention limited refugee status to Europeans who had been displaced due to events before it was signed, the 1967 Protocol removed these limitations (UNHCR 2010 [1951, 1967]: 51-52). 
as "ICTs" to describe the various machines and programs that humans have developed in order to facilitate the exchange of information between individuals and groups. I primarily focus on two types of ICT in my research: mobile phones and the internet. These two technologies are now often combined in the form of smart phones, mobile phones that are able to connect to the internet and perform a number of other functions traditionally associated with computers. Therefore, these two technologies must be studied together in any context where smart phones are available.

\section{Methodology}

Eight participants, age 26-40, were interviewed in Louisville as part of this study, including three women and five men. Five participants were SIVs (Special Immigrant Visa recipients), one participant was the wife of an SIV, and two were refugees with no special status. Two participants were employees and former clients of KRM and the other six were students in an English class held at KRM. All of the participants left Iraq after 2006 and arrived in the US after 2009. KRM staff indicated that, at the time of the study, the population of Sunni and Shi'a Muslims at KRM was roughly half and half, with a very small number of Christians served. Participants were not asked directly about their religion or sect, but clues based on their stories indicate that both Sunni and Shi'a individuals participated. The investigator took notes during each interview and, if the participant was comfortable with being recorded, a recording was made and later transcribed. Interviews were about 15-20 minutes each and took place at KRM. Questions asked pertained to the participant's trajectory of flight, his/her occupation, his/her parents' occupations, his/her family and social network structure, how he/she accesses technology, what technology he/she accesses, with whom he/she communicates, how he/she 
communicates, and in what language he/she communicates, [see Appendix I: Interview Questions]. Pseudonyms were assigned to all participants (refugees and staff). All refugees interviewed were proficient in and were interviewed in English.

In Amman, Dr. Haitham al-Zou'bi of Terre des Hommes connected me with volunteers at the East Amman Association Center in Marka and the Noor al-Hussein Association Center in Hashemi Shamali. Nine individuals were interviewed in South Marka and five individuals were interviewed in Hashemi Shamali. One individual was a volunteer for the East Amman Association and the others were community members who are beneficiaries of the centers. Included individuals were adult refugees who sought asylum in Jordan after the 2003 Iraq War and the events that followed. Two interviews were omitted from the analysis because the interviewees arrived in Jordan before 2003 and therefore did not meet my inclusion criteria. In addition, two semi-structured interviews were conducted, one with the director of the East Amman Association Center in South Marka and one with a social worker at the Noor al-Hussein Association Center, to determine what the functions of the centers are, what services are provided, and what populations are served. Demographically, the sample group used in this study was a mix of ages and genders, aged between 18 and 64 with seven men and five women. The average age was 42 ; most participants were older adults who were married or divorced and had children. Only two participants did not have children.

Each interview lasted about ten minutes, although some were longer because the participant wanted to discuss other topics. Most participants interviewed in Amman had poor English skills and so interviews were shorter and less in depth that those conducted in Louisville. All individuals participated voluntarily and they were briefed on their rights as research participants. For the safety and comfort of interviewees, all interviews were conducted 
anonymously. I asked my participants for permission to use a recording device and transcribed six interviews. For all other interviews, handwritten notes were taken. The interviews were semistructured and consisted of a series of predetermined questions as well as additional questions for clarification purposes.

Interviews in Amman were far more challenging than those conducted in Louisville. I had been a volunteer at Kentucky Refugee Ministries for over eight months when I began to conduct interviews there and so I had spent time with many of the men and women with whom I was talking. Interviewees were generally comfortable with my presence. This was not the case in Amman, where all of my interviews took place within a one month period. I was unable to interview some refugees in a private setting because they felt uncomfortable meeting with me alone. In the East Amman Association in South Marka, most interviews were conducted in a hallway outside of packed classrooms and some individuals insisted on speaking to me with the help of a friend with better English proficiency. While in South Marka, Iraqi and Syrian refugees constantly begged me for help in their attempts to leave Jordan and come to the United States. Some of their willingness to participate in the research project was colored by this desire.

Interviewing participants at the Noor al-Hussein Association Center in Hashemi Shamali was a unique and edifying experience because some participants seemed openly suspicious of my intentions. This should not be a surprise, since the participants were all members of a support group aimed at helping Iraqi refugees deal with the stress of displacement and trauma from the war. A staff member from the center was required to stay in the room with me while I was conducting interviews due to the organization's policy. At first, I felt that her presence was disruptive, but, as the interviews progressed, I was thankful that she was in the room. She provided a sort of official stamp of approval for me, the new foreigner. Under ideal 
circumstances, I would have been able to develop a better rapport with participants in Amman, but this was not possible due to the short period allotted for research.

\section{Literature Review}

Refugees and ICTs

While new communication technologies spread quickly, the literature available on refugees' use of ICTs remains limited. Scholars have appealed for more research on the subject because of the increasing significance of online communication to the resettlement process in the US (Flemming 2011). Studies have been conducted on the economic benefits of access to Internet cafes in Sub-Saharan African refugees camps, including better access to remittances and sponsors and access to educational resources (Omata 2011; Ionita 2011; Nabwowe-Kasule 2011) and on ways to facilitate communication using technology (Leung 2011; Leung and Lamb 2009). The Refugees United Project seeks to reunite refugees and displaced persons with lost family and friends using the Internet, on the ground in Kenya (Kiama et al. 2011:35-36) and worldwide on their website (http://www.refunite.org/). As a generalization, access to new communication technologies has benefited and empowered refugees.

The ability of non-governmental organizations (NGOs) to communicate with the communities that they serve is vital. Therefore, most of the studies pertaining to communication patterns in refugee communities seek to find effective ways to disseminate information on available services and aid. In a 2010 assessment, Noel Calhoun, Senior Community Services Officer for the Office of the UNHCR in Amman, Jordan, tested the widespread belief that Iraqis are distrustful of other Iraqis and don't network well because they are spread out in urban areas. Based on focus group discussions and community visits, Calhoun concluded that Iraqis 
demonstrate both significant bonding social capital (social involvement with people of their nationality) and bridging social capital (social involvement with people not of their nationality), although the former was significantly higher; therefore, this previous assumption was proved false within the assessed community. This assessment included a section on information sources, which determined that, within the participant population, the average male and female youth (1524) used the internet slightly more often than weekly, the average adult male (25+) used it more than once a month but not weekly, and the average adult female (25+) used it monthly (Calhoun 2010:9). Calhoun recommends that UNHCR use the internet more to disseminate information and mobilize the Iraqi community because, although the television is more widely used as an information source than the internet, "...the internet is a much less expensive means of disseminating information, and it has the advantage of allowing inter-action and the formation of social ties" (ibid 23).

Research on Iraqi refugees' assisted and self-repatriation from Syria and Jordan, a topic crucial to NGOs as they attempt to persuade displaced Iraqis to accept aid for returning to Iraq, has found that Iraqi refugees' use an information system based on informal sources, including the internet and mobile phones, satellite television, and circular migration to and from Iraq, to determine whether they will choose to repatriate and whether they will seek assistance to do so (Iaria 2011). These sources are distinct from government and other bureaucratic sources, which many Iraqis distrust based on their experiences prior to exile. In reference to the internet, Iaria writes, "The internet plays a growing role as a means of communication and information among the Iraqi refugees in Syria and Jordan, despite the limited regional access to affordable and efficient internet services" (ibid 45). She observes that most of her interview participants "use the internet only to acquire more personal information through online interactions with families and 
friends," (ibid 46). These observations closely match my preliminary observations while working with resettled Iraqi refugees in Kentucky and Jordan and so I predict that my results will closely match, complement, and expand on Iaria's.

\section{ICTs, Transnationalism, and the "Transmigrant"}

Anthropologists have utilized a variety of methods and theoretical approaches with respect to new digital media. Initial approaches to describing the effects of digital media heralded a new utopian "digital age" that would become the new modern (Coleman 2010:489). This idea is problematic, as it implies a teleology in which digital technologies are an essentially better form of cultural production and sets the stage for conceptualizing an underdeveloped other on the other side of the "digital divide" in need of assistance to become modern (ibid 490).

Anthropologists have challenged this idea, noting that technology may facilitate societal change, but it does not inherently cause that change; in fact, digital media can be used as a platform to "facilitate social reproduction" (ibid 489, Escobar 1994:211-231). This critique should not imply that new technologies are not a significant subject of ethnographic inquiry. On the contrary, transformations in human societies and cultural expression facilitated by new media have been the subject of much discussion within anthropological circles.

The parallels between diaspora and digital community are particularly compelling. Victoria Bernal argues that diaspora and "cyberspace" are similar developments, in that modern diasporas are a result of new transportation technologies and "cyberspace" is a result of new information and communication technologies (2010:661). She writes, "Diaspora and dispersal engender networked forms of community, and relations on the Internet, similarly, involve linkages among dispersed users," (ibid 661). Her analysis of the website Dehai, a site of 
transnational communication for the Eritrean diaspora, is notable for its characterization of the internet as a digital space, endowing it with an almost physical sense of place unencumbered by national borders.

This post-modern conceptualization of communication across borders leads us to a useful model of transnational migration: the "transmigrant". Transmigrants can be defined as “immigrants whose daily lives depend on multiple and constant interconnections across international borders and whose public identities are configured in relationship to more than one nation-state" (Glick Schiller et al. 1995). This category was initially created to describe economic migrants who remained invested in their communities of origin socially, politically, and financially even years after emigrating (Rouse 1999[1991]; Glick Schiller et al. 1995). Although the term transmigrant has continued to be used most frequently to describe migrants for whom economics are the strongest push and pull factors leading to migration, scholars have recognized the characteristics of transmigrants expressed by refugees (see Hyndman and WaltonRoberts 2000). While refugees are usually unable to return to their communities of origin, even for a visit, due to threat of discrimination, injury, or death, I argue that they are still dependent on what Glick-Schiller et al. would call "transnational social fields": dense webs of social connections that cross nation-state borders. It may even be useful to describe some transnational refugee communities as what Rouse calls "transnational migrant circuits", communities that have become so unified by the "continuous circulation of people, money, goods, and information" that "they have come to constitute a single community spread across a variety of sites" (1999 [1991]:14).

Adding to this movement in migration studies, Panagakos and Horst (2006) surveyed a variety of case studies dealing with transnational migrants' use of information and 
communication technologies (ICTs). They emphasized the common use of a variety of old and new ICTs, bundled in order to strengthen ties. They framed the internet as a contradictory space where marginalized groups who can gain access can form a strong community and produce their own media, but which is built on corporate marketing agendas and subject to surveillance. They stressed that the suitability of different ICTs is based on individual and social needs, availability, and access. Based on the work of Panagakos and Horst (2006) and recognizing that there is no natural hierarchy of communication methods, this study positions the internet as part of a larger bundle of communication methods, including mobile and landline phones, paper mail, and faceto-face communication.

In order to examine family relations across international borders, it is useful to examine the notion of "transnational caregiving". Loretta Baldassar et al. posit that "Much like ethnic, national and diasporic identities and relationships, family identities and kin relations can be maintained across time and distance and are not determined by particular localities or by state borders" (2007:13). They created a model of transnational caregiving as a "pattern of generalised reciprocity" based on capacity, obligation, and negotiated family commitments. Among migrant communities that used e-mail, they found that it was primarily used for quick, simple, daily communication and to schedule telephone calls (ibid 123). Most significantly, they found that people who were able to use multiple modes of communication established connections to more nodes (recipients of first-hand information) and therefore had stronger networks at home. Migrants and refugees with only one node (i.e. a single family member who receives calls or mail) risked losing contact with their family and friends in their country of origin if that node died or became incapable of sustained communication. Baldassar et al.'s research indicates that internet use might strengthen social bonds within communities simply because it creates the 
potential for many additional nodes in an individual's communication network and makes

existing nodes stronger by providing multiple possible alternatives for interacting with them.

\section{Arabs and the Internet}

The Arab world is a relatively new and growing demographic in the world of the internet. According to the United Nations Economic and Social Commission on Asia's (ESCWA's) report, "Status of the Digital Arabic Content Industry in the Region," "the Arabic language has jumped to seventh position in the list of top 10 languages of internet users by language for 2011" (5). The report emphasizes the demand for Arabic language content on the internet and highlights opportunities for economic growth in the Arab world based on the production of digital Arabic language content. It notes that, according to a market survey, $62 \%$ of internet users in Egypt, Lebanon, Saudi Arabia, and the United Arab Emirates prefer Arabic content in the internet, while 38\% prefer English (ESCWA 2011:20).

This study is based on the assumption that Iraqi and Arab cultures are compatible with the adoption of communication technology. However, not all academics agree on this issue. Karen Loch et al. surveyed a group of "middle and senior managers and knowledge workers" (2003:51) attending a technology conference in Cairo. They sought to determine the effects of technological culturation, which they define as “... the cultural exposure and the experiences that individuals have with technology originally developed in other countries" (ibid 46). They concluded that "Cultural obstacles to the diffusion of information technologies in the Arab world are significant, as noted by the respondents," but that exposure to Arabs with training in technology and foreigners from "technology-originating cultures" may overcome "certain cultural inhibitors" (ibid 56). 
Several aspects of this study, however, are problematic. The sampling method was flawed; although the authors claim that their results represent the Arab world, 85 percent of respondents were Egyptian and only 7 percent were non-Egyptians with an Arab nationality (ibid 52). In addition, they base their analysis on the existence of "advanced technology cultures," a category which they never clearly define, but which appears in many of their survey questions as "the non-Arab industrialized world." Moreover, they adopt a culturist approach which likely obscures the more significant economic factors that affect internet adoption. This study is an example of a developmentalist narrative in which the West must bring technology to the Arabs in order to "modernize" them. The "advanced" Westerner must be the agent and the Arab must be the subject in this interaction.

Wheeler (2004a; 2004b; 2008) provides a satisfying rebuttal to this study. She has written extensively on internet use in Kuwait, Egypt, Jordan, and the Arab world in general, particularly factors that affect women's internet use. She writes, “...the cost of internet use and lack of training remain real barriers to more widespread use of the internet by women in the Arab world," but, contrary to Loch et al., she argues against the assumption that cultural factors are slowing the adoption of internet. She also highlights the widespread use of internet cafes in the Arab world for access and training, which is not reflected in statistics on the region. In a more recent article (2006), drawing on interviews with internet cafe users in Egypt and Jordan, Wheeler identifies three themes commonly heard in internet cafe users' narratives about the internet: its use to cross gender boundaries, increase political and social consciousness, and improve job prospects and skills. Presciently, she concludes that growing trends of internet use may challenge the power of the state by providing rapid access to more information. Her conclusions were supported when the internet played such a prominent role in the Arab Spring. 
In Wheeler's narrative, Arab men and women are active agents who use new tools to express their own ideas and meet their own needs.

Wheeler's arguments have proved to be more compelling in the long run as internet proliferation has increased in the Arab world over the last ten years. Yet these contradictory studies do spark a question: what factors limit the proliferation of internet within the Iraqi refugee community? Literacy is clearly a factor: 24 percent of women and 11 percent of men in Iraq are illiterate and 25 percent of the rural population is illiterate versus 11 percent of the urban population (UNESCO 2010). Economic factors may also play an important role, as Iraqis can't find jobs in Iraq due to instability and refugees find it difficult to obtain work permits. Therefore, many find themselves in poverty. But why is Iraq so unstable? Why are so many people illiterate? Why are people compelled to leave? The historical record can help us answer these questions.

\section{History}

Iraq's history is vitally important to understanding the issues of communication and displacement in the Iraqi context. Attempts to explain the low proliferation of some technologies in pre-2003 Iraq fall flat without reference to the Iran-Iraq War, the first Gulf War, and the international sanctions regime, the combination of which crippled the Iraqi economy and educational system (Alahmad and Keshavarzian 2010:27). Within the same vein of reasoning, special attention will be paid to the history and current state of infrastructure in Iraq and regions with Iraqi refugee communities.

Iraq 1980-2003 
Iraq has been at war or under sanctions since the beginning of the Iran-Iraq War in 1980. It is clear that the sanctions regime and periodic violent conflict had a devastating effect on the country's infrastructure and the well-being of Iraqi citizens. This negatively impacted most Iraqis' ability to adopt new ICTs, as did state repression, and, more gravely, spurred periods of displacement throughout the late $20^{\text {th }}$ century and into the present.

Eight years of brutal war between Iraq and Iran (1980-1988) devastated the land and the people, finally ending with a stalemate and a begrudged truce. The US government had happily supported the Saddam Hussein-led Iraqi government against their common enemy, Iran, throughout the war. After the Iraqi invasion and attempted annexation of Kuwait in 1991, however, the US supported and enforced UN resolutions condemning the action and supporting Kuwait's sovereignty. US-led bombardment of Iraq and attack on Iraqi forces in Kuwait further damaged infrastructure that had yet to be completely repaired after the Iran-Iraq war (Alahmad and Keshavarzian 2010:26). Undoubtedly, "The considerable damage of the Iran-Iraq War to Iraqi infrastructure made the impact of the 1990-2003 sanctions more severe than what might have been otherwise," although we may never know the exact toll because independent estimates of damage from the Iran-Iraq War were never possible due to state restrictions and because coalition bombing began so soon after the war ended (ibid 27).

From 1990 until the US invasion in 2003, UN sanctions crippled the Iraqi economy, initially as a response to the invasion of Kuwait, then as punishment for the Saddam Hussein regime's refusal to pay reparations to Kuwait and the regime's inaction on the issue of destroying alleged "weapons of mass destruction". Under the sanctions and embargo on exports from Iraq, imports were limited to "supplies intended strictly for medical purposes, and, in humanitarian circumstances, foodstuffs" based on the determination of the Sanctions Committee (UN Security 
Council 1990). The Sanctions Committee denied such items as pencils, textbooks, and spare parts for ambulances (Center for Economic and Social Rights 1996:6). Essential institutions such as hospitals and water treatment plants fell victim to equipment failures that could not be repaired and lack of resources such as medicines and bleach (Center for Economic and Social Rights 1996). In 1997, The Oil for Food Programme allowed the Iraqi government to pay for basic rations by selling oil, but the money available was insufficient to provide for proper rations for those families in need (ibid 9; Graham-Brown 2000:9).

Sanctions had a detrimental impact on the quality of life in Iraq. As a result of poor medical and sanitary infrastructure, food shortages, and widespread poverty, infant mortality rates doubled between 1990 and 1999 (Garfield 2000). According to UNESCO, Iraq had one of the best educational systems in the region before 1991 (2003). In 1985, the adult female literacy rate was 85\% (Sen 2003). Between 1990 and 1998, UNICEF estimates that one fifth of Iraqi children stopped enrolling in school due to overcrowding and lack of economic resources (ibid).

In 2002, on the eve of the US invasion of Iraq, 400,000 recognized Iraqi refugees were already dispersed across the world, including over 200,000 in Iran (UNHCR 2003b). These refugees were a combination of those displaced by the Iran-Iraq War and 1991 Gulf War, Shi'a rebels fleeing reprisals from the government, individuals suspected of being Shi'a rebels, political enemies of the Saddam Hussein regime, and many others.

\section{US Invasion and Iraqi Refugees Post-2003}

On March 20, 2003, after months of condemning Iraq for failure to comply with UN resolutions on ending weapons programs and with shaky evidence (later proved false) that the Iraqi regime had failed to destroy stockpiles of weapons of mass destruction, the US military 
began a ground invasion and occupation of Iraq. It seems that the US had become emboldened by decisive victories in the 1990s and not only saw a chance to eliminate a regime hostile to the US and its interests in the region (including Israel), but a chance to raze the already weak government and economy and create a friendly democratic government that could, with a rebuilt, neo-liberal economy, become a profitable market for international companies (Mearsheimer et al. 2007:230; Klein 2007).

With the US invasion and occupation, sanctions were finally mitigated. Despite guerrilla warfare, looting, lack of services, and instability across the country, from 2003 until 2005, UNHCR reported a large number of Iraqi returnees and very few new asylum seekers compared to previous years $(2005: 371)$. This can be attributed to the return of many political refugees to Iraq after the removal of Saddam Hussein, which was the focus of refugee policy immediately after 2003 (Libal and Harding 2007). US forces dismantled the Iraqi military and the government to make way for new governance and economic liberalization, which caused widespread unemployment (Klein 2007). This made the already difficult economic situation even more dire and made staying in Iraq undesirable, propelling the journey of some early migrants.

By 2006, the stage was set for mass displacement. Increasingly, sectarian groups formed organizations to keep order in the streets and to fight US forces alongside the largely secular and/or tribal insurgency. These included the Sadr Organization, followers of the Shi'a extremist religious leader, Muqtada Sadr, and its militant wing, the Mahdi Army, and al-Qaeda's Iraqi branch, an extremist Sunni group, among others (Shadid 2006; Kukis 2011). These groups initially claimed to target for killings those who were collaborating with Americans, but it became increasingly clear to Iraqi civilians that they were instead targeting individuals not belonging to their sect (Kukis 2011). 
In February 2006, in an environment already ripe with tension between rival militias, Sunni insurgents bombed the Shi'a al-'Askariyya Shrine, located in the majority Sunni town of Samarra (Tripp 2007:306). Reprisals against Sunni mosques across the country followed, escalating sectarian violence (ibid). This event alerted international humanitarian organizations to the growing displacement of Iraqis (Libal and Harding 2007). Sunnis were fleeing Shi'a majority neighborhoods to escape Shi'a militias and Shi'a were fleeing Sunni majority neighborhoods to escape Sunni militias (Kukis 2011). Members of minority sects and Christians had few safe places to go and many left the country. Palestinian and Syrian refugees in Iraq were also targeted because they were perceived as privileged by the former regime (UNHCR 2005). The once cosmopolitan neighborhoods of Baghdad were forcibly homogenized by sectarian militias. In the north, even more people were displaced when Kurds and Turkmen clashed with Arabs who had been encouraged to settle in Kurdistan by Saddam Hussein's regime in order to dilute the Kurdish population and decrease its ability to resist the power of the state.

By 2008, 2.8 million Iraqis, or 5 percent of Iraq's population, were internally displaced (IDPs), 1.6 million of whom reported being displaced between 2006 and 2008 (UNHCR 2008). Many who could afford it left the country; in that same year, an estimated 2 million Iraqi refugees were in Syria and Jordan as well as another half million in other Middle Eastern countries, including Turkey, Egypt, Iran, Lebanon, and a number of Gulf countries (ibid). Today, those numbers have decreased to 746,440 refugees, 23,920 asylum seekers, and 1,131,810 IDPs according to official numbers (UNHCR 2013).

\section{Iraqi Refugees in Jordan}

Iraqi refugees and migrants began to arrive in Jordan as early as 1995, seeking political 
asylum from Saddam Hussein's regime and economic opportunities (Sassoon 2009:33). By 2003, somewhere between 250,000 and 350,000 Iraqis resided in Jordan, only 30,000 of whom were legal permanent residents (Sassoon 2009:33). After the start of the Iraq War, the scale of the refugee problem in Jordan became controversial. Between 2003 and 2007, the Jordanian government downplayed the refugee issue, giving Iraqis six month temporary residency passes at the border and categorizing them as "guests" who would soon move on, while many international organizations estimated the number of Iraqi refugees in Jordan as somewhere between 500,000 and one million (Seeley 2010). In April 2007, the Jordanian Interior Ministry appealed to the international community, claiming that Iraqis were "costing Jordan $\$ 1$ billion per year" and standing by a 750,000 refugee estimate (Seeley 2010). That same year, a survey of Iraqi refugees carried out by the Norwegian NGO Fafo estimated the Iraqi population as only 161,000 (Dalen and Pedersen 2007; Seeley 2010). The highest number of refugees ever registered with UNHCR in Jordan was about 65,000 (Seeley 2010; Zou'bi 2012). Despite Iraqis' distrust of aid organizations, which may have led to low registration, this number indicates that Fafo's numbers were closer to the truth. Today, the official government estimate of the Iraqi refugee population is 450,000, but only 29,000 are registered (UNHCR 2013).

The first waves of Iraqi refugees after the war began, nicknamed "Mercedes Refugees", were "businessmen and former government officials who supposedly brought with them billions of dollars" (Sassoon 2009:36). Following waves were less prosperous, but a stereotype of Iraqi refugees as wealthy dogged subsequent waves of migration. Iraqis took the blame for a number of economic problems in Jordan, although a Jordanian study points out that "inflation in Amman (where most Iraqis are located) is lower than Jordan as a whole from 2002-06, and for certain periods lower than many other governates in Jordan" (Sassoon 2009:50). 
The Iraqi population in Jordan is mostly urban, living primarily in Amman, Zarqa, Irbid, and al-Karak (Zou'bi 2012). For refugees, host countries like Syria and Jordan make access to work permits, education, and health care difficult to obtain (Mokbel 2007). 64\% of Iraqis in Jordan rely on money transfers from Iraq or a third country to survive as they can't work legally (Sassoon 2009:47). They fear the Jordanian government, especially the mukhabarat (Jordan's secret police), due to rumors that many Iraqis have been deported because they overstayed their six month residency or because they are Shi'a (Sassoon 2009:53). These factors have caused the Iraqi refugee community to become less visible, as they settle into low-income urban areas and avoid contact with their host governments, doing little community organizing (Peteet 2007; Libal and Harding 2007). Paradoxically, the cultural similarities between Iraqis and Jordanians lead to greater social interaction and community building between the two groups than might be expected in another context and so the populations profoundly affect each other.

Some Iraqis move many times in search of an income to support their families, traveling in and out of Iraq and border countries. Most Iraqis see Jordan as just a stop in a larger resettlement process; between 2010 and 2012, at least 8,180 individuals were resettled from Jordan to third countries (UNHCR 2010; 2011; 2012). Although Iraq is still not completely safe, many are now returning because they can no longer survive in Jordan and their options for resettlement are limited. The Iraqi population is looking more and more permanent, with many Iraqi families who fled the Second Gulf War having been in Jordan now for almost ten years.

\section{Refugee Resettlement in the US}

Between 2003 and 2007, the US accepted only 500 refugees from Iraq, in contrast to the thousands they had accepted each year prior to the invasion (Peteet 2007:224). During this 
period, the US administration seems to have been in denial, claiming that the displacement problem predated the occupation and had nothing to do with current events (Peteet 2007; Libal and Harding, 2007). Finally, in 2007, under international pressure, the US agreed to increase its intake of Iraqi refugees. Since then, 84,902 Iraqi refugees have been admitted to the US, not including the 25,000 SIVs (Special Immigrant Visas) that were available by the end of 2012 and the additional 2000 visas added when the program was extended last year (USCIS 2013). Refugees in the US can easily obtain permission to work and can eventually apply for citizenship.

Louisville has welcomed refugees from Iraq since the 1980s and 1990s, but in very small numbers. John, an English teacher at Kentucky Refugee Ministries (KRM) since 2002, doesn't remember meeting an Iraqi in Louisville before 2007 when they began to arrive in large numbers. Until May 2011, when two Iraqi men were arrested in Bowling Green on charges of attempting to provide weapons to al-Qaeda in Iraq (Frieden 2011), the Iraqi community was one of the largest served by KRM. KRM staff members say that since then, very few Iraqis have been brought to Louisville while the government works on redesigning its vetting process. In the summer of 2012, non-SIV Iraqis finally began to enter Louisville in greater numbers again, many in the wake of violence in Syria.

Louisvillians often view Iraqi refugees with suspicion because of the widespread distrust of Muslims and Arabs that has become endemic in the US. Class disparities within the Iraqi community mean that Iraqis face a variety of challenges. I use class to refer not only to economic status, as even Iraqi refugees who were very rich when they left Iraq may find their resources drained after years in a country of exile where they are unable to work legally. Class here refers to a combination of level of education obtained, economic resources, occupation, and social 
connections that provide power.

Upper class Iraqis tend to be more highly educated and know at least some English, making it easier for them to be placed in a variety of jobs, but refugees with higher education and/or professional degrees must re-certify when they come to the US. Re-certification is a long and expensive process for professional like engineers, doctors, and lawyers, so many are compelled to take lower wage jobs or enroll in technical school to support their families. Many upper class Iraqis also come to the US with some money, so they can afford better amenities when they first arrive.

Iraqis from the lower classes aren't as well educated as their upper class counterparts; many never attended secondary school and some are illiterate. Their limited English makes job placement a challenge. Some under-educated Iraqis must rely on their children, who usually learn English much faster, creating a troubling reversal of power in the household. Still, KRM employees agree that whether they were rich or poor in Iraq, Iraqis are usually very selfsufficient and eager to learn.

Most of the participants in this study who were resettled to the US are enrolled in the SIV (Special Immigrant Visa) program. There are two programs for SIVs - one was authorized in 2006 and applies only to Iraqi and Afghani translators and interpreters and the second, authorized in 2008, applies to Iraqis who worked for or on behalf of the US Government in any capacity, even those who worked through contractors (Bureau of Consular Affairs 2013). An SIV must have worked for or on behalf of the US government for at least a year after US military presence in Iraq began (ibid). Both programs allow participants to bring their spouse and children. These programs were established in response to targeted attacks and death threats by locals militias aimed at individuals who were associated with the US occupation. Many participants recalled 
living at work for long periods of time because they were afraid for their lives if they left the Green Zone (the International Zone located in Baghdad) for too long. SIVs are generally resettled more quickly than other refugees and they are transported directly from Iraq to the United States, without having to cross another border before applying for SIV status. They therefore do not meet the definition of a refugee set forth by the UN Convention and Protocol Relating to the Status of Refugees when they are accepted into the program, but they qualify after they are transported to the US.

\section{Internet in Iraq}

Internet connections in Iraq were first established in 1998, but their use was limited to government officials (Arabic Network for Human Rights Information 2004:41). Unauthorized use of modems was prohibited until the end of 1999 and so internet access was not available to most computer users until 2000 (ibid). Even then, the internet was heavily censored and monitored by the state. Public access was available at 65 internet centers staffed by government officials where most web sites were blocked and e-mail was only available through a government-supported subscription service, the General Company of Internet and Information Services (GCIIS) (ibid; Ghattas 2002). Staff at the centers physically monitored individuals computer monitors and authorities intercepted and read e-mails, delaying their arrival time (ibid). Due to the poverty of most Iraqis under international sanctions and embargoes against electronics, only the wealthy could afford a computer, modem, and subscription fee from the one government service and the resulting computer was a highly limited information system (ibid). Mobile phones were also uncommon because their import was illegal and thus expensive. Information technology proliferation increased rapidly after the US invasion in March 
2003. More than a decade of economic sanctions were lifted and legal imports of cell phones and computers quickly flowed into Iraq. According to a 2005 ESCWA report, mobile subscribers in Iraq increased from 0.10 million in 2003 to 1.59 million in 2004. The same report indicates that there was an $80 \%$ increase in Iraqi internet users from 2003 to 2004. Internet censorship was lifted, opening an uncensored space to many Iraqis for the first time. Despite this new availability of foreign electronics, most Iraqis were and are now still unable to connect to the internet because the communications infrastructure was badly damaged due to bombing during the Gulf War and the 2003 US invasion and had not been maintained and updated properly due to international sanctions. The electrical infrastructure was in similarly poor condition and power outages often forced people to use generators for long periods of time. There was also still only one internet service provider (ISP).

In 2010, only 1,600,000 fixed line phone subscriptions were registered in Iraq, while 24,000,000 mobile phone subscriptions were reported (ESCWA 2011:18). Assuming that these mobile phones are each used by only one person, this means that 76 percent of the population has access to at least one cell phone. This reflects both the popularity of mobile phones and the unreliability of fixed line phones, which has prompted the need to bypass land lines.

Improving telecommunications infrastructure has been a top priority of the Iraqi Ministry of Communications. Like many similar projects in postwar Iraq, these improvements rely on private investment (Iraqi Ministry of Communications 2012). Gulf Bridge International is currently building an undersea cable system intended to make Iraq a telecommunications hub connecting Asia and Europe more efficiently (Pfanner 2012). As of 2010, only 6 percent of the Iraqi population has access to the internet, with men reporting internet use twice as often as women (ESCWA 2011). Between 2004 and 2007, the number of registered internet cafes in Iraq 
doubled (Iraqi Ministry of Communications 2008). Operated by Iraqi entrepreneurs, their atmosphere was gendered to a varying extent; some women reported feeling uncomfortable in dedicated internet cafes (Majeed 2009). Cafes are traditionally male space in the Middle East and so the exclusion of women from a cafe environment is not unusual. Unsurprisingly, telecommunications infrastructure is much better in Iraq's major cities, so urban communities have better access to the internet. Literacy also affects access to the internet, as 24 percent of women and 11 percent of men in Iraq are illiterate. 25 percent of the rural population is illiterate versus 11 percent of the urban population (UNESCO 2010). Sanctions and war exasperated the rural/urban gap and devastated the Iraqi education system. While Arabic web content is becoming more common, most web content remains only in English. Although users can translate pages with services like Google Translate, translations are not reliable and affect the quality of web content.

\section{Internet in Jordan}

The context of exile profoundly affects the ways in which Iraqis are able to communicate effectively and economically. Jordan, an Arab country with a rapidly growing population of internet users and impressive mobile phone proliferation, is a context that facilitates the use of ICTs. Jordan, in contrast to Iraq, has long attempted to keep in stride with global telecommunication trends. Jordanians first accessed the internet in 1994 and, unlike some Arab countries, access was always available to the general public (Warf and Vincent 2006:86). By 2006, a street in Irbid, Jordan had the unique distinction of making the Guinness Book of World Records for having the "highest concentration of internet cafes anywhere in the world" (Warf and Vincent 2006:86). Online media do not face the same censorship and regulations as print 
news media, although recently proposed amendments to the Press and Publications Law may change that record by requiring websites to regulate user comments (Ghazal 2012). ESCWA reports that, between 2009 and 2010, Jordan had the third highest growth rate in number of internet users among countries in the Western Asia region (ESCWA 2011:19). As of 2010, 51\% of Jordanian homes reported having a computer (ESCWA 2011:22) and 38\% of Jordanians were estimated to have internet subscriptions (Information \& Communications Technology Association - Jordan 2011). Wheeler contends that internet proliferation rates in Jordan may be higher than reported in official surveys because these surveys only count the number of internet subscriptions, not taking into account the large number of internet cafe users (2006). Internet users are concentrated in urban areas, but internet connections are available even in rural areas with $3 \mathrm{G}$ wireless cards.

Mobile phone use has become nearly universal in Jordan; according to Information \& Communications Technology Association - Jordan (INT@J), there are 6,620,000 mobile subscriptions active in Jordan, a number that has surpassed the official population of the country (2011)! This $108 \%$ mobile proliferation indicates that many individuals have multiple mobile phones. In contrast, fixed line subscriptions are clearly unimportant to the general public, as there are only 485,000 fixed line subscriptions open countrywide (INT@ J 2011). Smart phones are, while expensive, widely available across the country, even in rural areas.

The environment for use of ICTs in Jordan is thus extremely favorable, as a variety of services are accessible and ICTs are widely proliferated, even in rural areas.

\section{Data}

Iraqi Refugees in Amman

The East Amman Association Center in South Marka is nestled in a back street. It's 
surrounded by old, dilapidated apartment buildings crowned with giant barrels where the inhabitants store their water and clothes lines where they dry their laundry. Marka is in east Amman, the poor side of town, and is mostly inhabited by families of Palestinian, Iraqi, and Syrian refugees. In the mornings and afternoons, the many housewives, unemployed, and underemployed residents of the neighborhood and their children congregate in the narrow hallways and classrooms of the center. In Hashemi Shamali, closer to the center of town, a medical center funded by the charitable foundation of Jordan's former queen Noor al-Hussein hides in a nondescript building behind a local mosque. In a conference room on the third floor, once a week, a group of men and women from nearby neighborhoods gather to discuss the challenges of living life normally after experiencing the trauma of war.

These two sites were the locations where I met and interviewed a diverse group of Iraqi refugees during fall of 2012. Most were born and raised in Baghdad, with the exception of one who was born in Kuwait and one who was born in Basra, both of whom were living in Basra when the 2003 War began, and one who was born in Dhi Qar Province and moved to Baghdad before the war. Many respondents reported moving multiple times within Iraq before fleeing to Jordan. Two participants fled to Egypt and then moved to Jordan from there and one initially fled to Syria before moving to Jordan. Only one participant had returned to Iraq since her exile, to visit her elderly and sick mother.

Iraqi families are extended and tight knit and, since mass displacements began in the 1970s, they have become scattered. All but two participants had family members still in Iraq. Two participants had family in an Arab country other than Iraq, one in Saudi Arabia and one in Kuwait. Ten out of the twelve participants had family members in Western countries, including some in Sweden, the US, the UK, Australia, and the Netherlands. All of them reported that they 
talk to their family in other countries regularly, most of them once a week or more. Zeena, a softspoken woman in her early thirties whom I met after a conference on the importance of keeping your children in school, said, "My sister is in America. She went there eight months ago... She is homesick, so I talk with her a lot to keep up with how she's doing." Zeena is her sister's moral support and she badly wants to join her in Ohio. At the end of our interview, she became louder and more animated as she asked me if there was any way I could help her join her sister in Ohio. Safia, a housewife in her early forties, worries for the safety of her family in Iraq and likes to be able to check on them regularly to make sure they're still doing well. In 2010, she went so far as to return to Iraq because her mother was ill. Typically, in Iraq, these individuals would regularly visit with members of their extended kin. Without visits as an option, communication with extended family helps Iraqi refugees to maintain and reconfigure the sense of belonging that is normally associated with geographically close kin.

The method that Iraqis use to communicate with family depends greatly on geography and the way it affects cost and access. Many respondents said that they use the internet to talk to their relatives in countries other that Iraq, but they call their relatives in Iraq on the phone. Even when they talk to relatives in Iraq on the internet, the poor internet service in Iraq affects the connection. When asked about her internet connection, Zeena responded, "When I talk to my sister in America it's good, but when I talk to people in Iraq, no.” Also, because the caller must pay for the price of the phone call, who makes the call is significant. Thamar, a former soldier in his early fifties, explained that he calls his family in Iraq and the US once a week, but his family members in London call him once a week because they can get a better deal on international calling cards in the UK. Hashim, a 50-year-old man who I interviewed in Hashemi Shamali, says that it's too expensive for him to call his family, but that his family calls him often. 
Maintaining relationships with friends using communications technology seems to be less valued than keeping in touch with family. Most of the interviewees said that they talk to their friends face-to-face or set up times to meet on the phone. Eight of the participants use Facebook, but they say they even use Facebook more to communicate with family than friends. Older individuals seemed just plain confused when I asked them if they talked to friends online, as if the idea of it seemed silly. Many of the participants from the East Amman Association Center said that most of their friends were from the Center, especially the women. The participants who reported that they use the internet to socialize with friends were those in the 18-35 age group Sahar, Walid, Zeena, and Rashid. Rashid, a 28-year-old father who originally came to the Noor al-Hussein Center to seek treatment for his disabled son, even said that he keeps in touch with friends from his time in Syria. This indicates that there is a generation gap in communications technology use, whereby younger people spend more effort on building friendships online than older users.

Every individual interviewed owned a cell phone; some even owned more than one. Samad, a man in his early fifties who attended the meeting in Hashemi Shamali, proudly showed me his two mobile phones, one of which he only uses to talk to IOM, UNHCR, and other aid and resettlement organizations. A few of the older men owned smart phones, which they seemed very proud of, but they did not identify them as the primary way they connect to the internet. They value them because they are expensive luxury items.

All but two participants, Marwa and Qassem, could access the internet at home with a computer. Marwa, an older woman, seemed uninterested in computers or the internet, saying in a dismissive tone, "My husband is always too busy for this. He is always at work and he has no time to communicate on the internet. And I am not educated in the internet." On the other hand, 
Qassem, a short, gray-haired man and the oldest participant, had just enrolled in a class on using computers at the community center in Marka. He often goes to a friend's house to talk online with his help, but he says he finds computers hard to understand and he has trouble learning. But he was obviously excited to learn, smiling from ear to ear as he said that he likes the internet and that it makes people happy.

The most popular programs among the internet users surveyed are Facebook, Skype, Yahoo Messenger, and various e-mail clients. Yusuf, a former translator for the US Army and former officer in the Iraqi army who was delighted to have someone with whom to speak English, uses websites that help him practice his English. All of the internet users connect at home and they say that the connection is good most of the time. Samad, Thamar, and Rashid say they use $3 \mathrm{G}$ USBs to connect. New on the market, these devices allow one to buy internet by the gigabyte and use it on a computer with a USB port anywhere within range of a cell phone tower. Sahar, Safia, and Rashid, the three interviewees who fled from Iraq to another country before they moved to Jordan, all had good internet access in the other country. Rashid says that internet in Jordan is more expensive than in Syria, but that the cost of living is less in Syria in general and that "the cheapest thing in Jordan is the communication." Sahar and Safia both speak positively of their home internet access in Egypt.

Only two of the respondents, Hashim and Thamar, reported that they had an internet connection in Iraq. Hashim was the only one of the two who said he had a good connection. Thamar said that he managed to get a poor connection in his home because he had a friend who bought the special authorization required to use the internet at the time (under the Saddam Hussein regime). Sahar recalls that her uncle had internet when she was in Iraq, but she was a child and doesn't remember how he connected. Walid, a very serious man in his early thirties 
who volunteered at the community center in Marka, used the internet for research when he was in college in 2002, but his family didn't have a connection until after he left the country and he had never used a computer for non-academic reasons before he fled to Jordan. Most participants said they didn't have internet in Iraq because there was none, but there were other interesting reasons given. Samad and Rashid gave the year 2006 specifically as the year when the people of Iraq started to access the internet. Yusuf said he didn't bother with the internet in Iraq because "I don't need at that time because I was living with my family." He also described how hard it was to get even a poor connection, but seemed confident that he could have had one if he really wanted it. I was surprised when Zeena told me that she went to a school for computers, but never had internet access in Iraq. She responded, 'It's because when I was in Iraq I didn't stay in one place. I moved from house to house. My husband was going to different stations. We had no stability. I didn't have a house.” Instability seems to have contributed in some cases to participants' inability to use the internet. Mobile phones seem to be preferable for refugees who are in a state of constant flight; using computers when laptops aren't widely available (they seem to have been and still are an extreme luxury) and wi-fi is rare just isn't practical or feasible. Cell towers and mobile phones were far more common.

In Jordan, a whole different set of access issues are in play. Mobile phones may be widely available and cheap, but service cards can be expensive. Respondents from the Hashemi area explained that international phone cards have recently entered the market, making international calls much cheaper than they were previously. Price is an internet access issue voiced by some respondents, but because it is possible to buy data downloads and uploads by the gigabyte, pricing is easier to control than in many other countries. If one uses the internet sparingly and avoids websites with videos, one can make a five JD (Jordanian Dinar) card last for weeks. Safia 
mentioned that sometimes she can't pay for the internet if money is tight. Nonetheless, the fact that all but one of those interviewed were members of economically disadvantaged families currently receiving aid indicates that an internet connection is considered worth the financial burden.

Some Iraqis in Jordan voiced significant security concerns with both mobile phones and the internet. Generally, women seemed to be concerned only with typical internet security issues, like not sharing your name and avoiding scam artists. Najia, a chatty housewife in her late forties who periodically greeted friends as they passed through the conference room where we were sitting, summarized these feelings well, saying "It is not safe... People will try to steal money from you... Because I don't know the people who I connect with them, it's not safe to give my information." Most felt safe sharing photos and their names with trusted people whom they'd met. Zeena mentioned that she occasionally sends pictures of her children to her family. Men were far more wary. Walid, Hashim, Samad, Thamar, and Rashid all mentioned concerns about possible government surveillance. Hashim is a Sabian, a member of a small religious minority, who fled his home when his car shop was attacked because of his religion. Still a member of an unrecognized minority in Jordan, he complains of discrimination and fears the government. Walid, Thamar, and Rashid say there is no safety on the phone or the internet and say there are some topics that they only feel comfortable talking about in person with people they trust. Thamar and Rashid refused to be interviewed unless they could be together in the office where the interviews were being conducted. They viewed me with clear suspicion. Thamar, a former colonel in the Iraqi army, said that he knows what governments can do from his time in the army and it scares him. Walid pronounced solemnly that "intelligence and police are in every country." Samad says that he feels safe saying most things on the phone, but he thinks the internet is more 
secure, so if he wants to talk about a sensitive topic, he prefers to use the internet.

Lack of education roughly correlates with an inability to use the internet. The two individuals who did not use the internet reported that they didn't know how to use it and this was a primary reason why they didn't have access. In addition, both of these individuals had low levels of general education compared to the rest of the group. Marwa did not finish high school and Qassem did not finish secondary school. However, this correlation is not particularly conclusive, as Sahar and Safia had also not completed high school and reported regular internet use.

In sum, how do Iraqi refugees in Jordan use communications technology? Based on this set of interviews, it seems that Iraqi refugees in Jordan use both mobile phones and the internet, although they use cell phones more regularly. They primarily contact relatives in Iraq and other countries, although young people (18-35) also keep in touch with friends. Older individuals find the idea of using the internet to keep in touch with distant friends strange and use mobile phones to set up physical meetings with friends. Most participants had never used the internet before they left Iraq and say that internet connections in Iraq are still poor. All participants call relatives at least once a week and those who use the internet chat between calls. Internet users connect from home and have a good connection in Jordan as a rule. Popular programs and sites include Facebook, Skype, and Yahoo Messenger. Iraqi refugees face a number of access issues that limit their use of ICTs. These include the price of phone cards and internet access and security concerns. Education may also be a significant concern, but more data would be required to determine the extent of education's effect on accessibility. There was no evidence that sociocultural factors significantly affect access to ICTs. 


\section{Iraqi Refugees in Louisville}

KRM rents half of an old mansion in a trendy neighborhood of Louisville. Several rooms on the first floor and in the basement have been converted into classrooms and the second and third floors are offices where various services are provided to the many refugees that come and go every day. The Iraqis I interviewed were some of the many refugees from throughout the world who take advantage of this agency's services. In many ways, their experiences and challenges in the US are much like those of their fellow refugees from Burma, Bhutan, or Somalia; they're exceptional, however, because of their habitual utilization of ICTs.

Despite limitations on service before 2003, many participants in this study had accessed the internet long before then. One had used it while living in the UAE in 2000. Three others had been exposed to the internet much earlier, one as early as 1998. Ahmed, a 27-year-old SIV, had an e-mail address in 1998, but didn't have regular internet access until 1999. Musa, a 39-year-old SIV, told the story of how before 2003, during power cuts, one of his friends continued to use his computer, downloading and writing programs with the monitor off to save energy. Ahmed and Nasr, a 26-year-old refugee, both did computer related work - Ahmed ran a computer shop starting when he was 16 years old and Nasr worked for an internet service provider starting in 2008. On the other hand, Hamza, a 32-year-old SIV, didn't know what the internet was until 2003 and he didn't know how to use it until an American IT specialist who was working with him in the court system taught him how to use it and set up his first e-mail account in 2004. Three participants simply stated that internet use was "forbidden" before 2003, one with the caveat that some people could get online by crossing a lot of red tape. One interviewee wasn't online until she fled to Syria in 2006.

All of the refugees interviewed were living in Baghdad when they last lived in Iraq. All 
but one was also born there; Lama, the 29-year-old wife of an SIV recipient, was born in the rural Babil Governate south of Baghdad. She is unable to contact her parents, her brothers, or her sister who all live in Babil using the internet because service is so bad there. In addition, international phone calls to Baghdad are cheaper than calls to the rest of the country, so she is compelled to pay about double the rate that her husband pays to call his family in Baghdad when she wants to call home. With phone cards, she pays $\$ 5 / 30$ minutes. Lama's experience makes it clear that internet is not an option for many rural Iraqis. Iraq also does not currently have a postal service, so telephones are the only option and they aren't reliable in all areas.

Iraqis in the US use a variety of free services in order to avoid the expense of longdistance calls. These include Viber, an internet calling service for smart phones, WhatsApp, an internet texting service, Yahoo Messenger, a messaging and video chat service which can be accessed with a computer or a smart phone, Skype, a video calling service that can also be used on smart phones and computers, and many others. Sometimes text-based communication is the most appropriate because internet in Iraq can only handle video calls at certain times of day and the time zone difference is extreme, but outside of Iraq, all of these services can be used without limit. Although the initial cost of a smart phone is high and so is the monthly cost (\$55 at Cricket, a popular service provider among refugees because it doesn't require a contract and is relatively cheap), those who can afford to buy one do because it provides the freedom to talk with loved ones as much as they want when they want. For example, Hamza's British wife currently resides in Scotland, but they chat for three or four hours every night.

Respondents prioritized family members in their communication habits, either expressing a strong connection with their family or citing family obligations. Participants in this study had brothers, sisters, and cousins in Iraq, Egypt, Germany, France, the UAE, Michigan, and Texas. 
Musa remembers visiting all of his extended family - six aunts, three uncles, and all of their children - in two days before he left Iraq out of a sense of duty. Hanin, a 34-year-old refugee, came to Louisville with her parents, but all the other participants left them in Iraq. It is not uncommon for an Iraqi man or woman to live in his/her parents' house until he/she is married. This was not possible for SIVs because of the dangers involved in their work, but many still identified their parents' house as their home before they left Iraq. Ahmed and Musa are trying to bring their families to the US and seem especially close to them. Ahmed joked about how his mother is always calling him to ask him questions; then his tone became very serious as he said, "without that technology she would feel very lonely and, to be honest with you, same to me." Musa and Nasr chose to come to Louisville in particular to reunite with family members.

Participants' modes of communication with friends differ from their modes of communication with family. Facebook is generally used more often with friends, but many Iraqis have security concerns about it. Hamza reads other people's posts on Facebook, but never posts or comments, because he fears that his friends' friends might not be trustworthy. He says, "To me it's like a newspaper from my home, reading daily, just in the morning about five minutes to see what's people doing and then that's it." Nasr uses Facebook to get the "news" from home as well. Ahmed, like Hamza, is cautious, but he says he feels safe because he knows what to share. He never posts pictures showing where he is because he says people are searching for his name. Nasr, Mahmoud, and Musa say that unlike some of their fellow Iraqis who worked for the US government in Iraq and remain very cautious about what they say on the phone or online because they still fear reprisals and government surveillance, they have little to hide and feel comfortable communicating.

Quick and cheap communication is important to people with relatives in Iraq because of 
the continuing dangers faced by those living there. After bombings and attacks, communication networks spring to life as Iraqis attempt to account for all of their loved ones. Mahmoud said that when violence became intense in Iraq, many people did a sort of "head count" on a daily basis to make sure no one was missing. Musa says that, when bombs would go off in their area, everyone would call their friends and relatives to ask them "Where are you?" Ahmed says that if he couldn't easily contact his family while outside of Iraq, he would have never left. His brother was killed in the street only twenty days after his marriage and since then, he has constantly worried about his parents and his sister, who still live in the same neighborhood where his brother was killed. He says:

If I cannot communicate with them and I hear that on the city news they've got all these bombs and explosions in Iraq, I would get mad, I would go crazy! The other day there was like, very near explosion near to my father facility, ok, and I was like getting really crazy frustrated because I don't know if he's (pause) God forbid it if he gets hurt or something...

The ability to communicate with loved ones is vital to Iraqi refugees' mental and emotional wellbeing because many, like Ahmed, live in fear of losing their friends or family to the violence that they have escaped.

ICTs can be a life preserver for refugees who are thrown into Louisville on their own, often with little knowledge of the area and few contacts to assist them. Their healthy adjustment to life in the US can be facilitated by the ability to contact people at home and connect with something familiar. Mahmoud remembers, "I've visited a family [in Louisville] they left literally they left Yahoo Messenger on with the camera on so they were like live, you know. It was like a reality show!" In addition, ICTs help refugees to become more connected to their new community. Various online translation services can provide limited English language help when a human translator is unavailable until refugees' English skills improve. Young people especially 
collect phone numbers and Facebook names from new acquaintances in Louisville to cultivate connections. Even before they arrive in the US, they use their social networks to contact Iraqis who are already in town, even those whom they've never met. These friends of friends and distant relatives are invaluable to the adjustment process because they give advice based on their experience of resettlement. Often, Iraqi clients at KRM know that a new person is coming weeks before they arrive.

Based on these interviews, observations, and discussions with KRM staff, it's clear that Iraqi refugees in Louisville are very willing to learn and adapt to new ICTs and that most have incorporated them into their lives. Cell phones are the most important tool for communication among Iraqis because they are relatively inexpensive, require less infrastructural security (in the case of $3 \mathrm{G}$ enabled phones), and convenient in emergency situations. In the US, communication using smart phones and the Internet allows Iraqi refugees with some savings to regularly maintain strong networks with their families. These refugees build strong networks of communication by bundling many modes of communication and programs for communicating with different people. One refugee may use Viber, WhatsApp, Facebook, Skype, Yahoo Messenger, e-mail, international phone calls, international texting, and many other methods to contact different nodes, such as family members, friends, and acquaintances. No participant in Louisville used just one method to contact everyone; even Lama, whose ability to contact home was the most limited due to her rural origins, mentioned that her husband uses an iPhone to keep up with his family and her friends are constantly pressuring her to join Facebook. All ICTs reported in this study, however, either require Internet access or phone service, which cannot always be taken for granted when many Iraqis are still in dire economic straits.

Iraqis in Louisville are extremely resourceful and take advantage of the widespread 
availability of ICTs in the US to facilitate their transition to their new home. They utilize their social and, specifically, kin networks for support despite geographic boundaries and distance that might otherwise make this impossible. Technology helps them not only to preserve existing social relations, but to create new ones and adapt to a new cultural space.

\section{Conclusion}

How do these two groups of Iraqi refugees compare? The sample group surveyed in Louisville, KY was far younger, with an age range of 26-39. Eight participants were interviewed, six of whom were SIVs, former translators or former employees of American contractors. All participants spoke English, were well-educated, and came from fairly wealthy families. They were young professionals from Baghdad ready to start work in the US and bring the rest of their families to live with them in the near future. Most of them left Iraq much later than the individuals interviewed in Jordan - between 2006 and 2012 as compared to between 2003 and 2012, with all but one in the US group not leaving Iraq until 2009.

Yet despite significant demographic differences, some conclusions about these two groups remain the same. Iraqis interviewed in the US still prioritized speaking with their families over their friends and a number of their family members could only be reached with the use of cell phones. Like Iraqis in Jordan, they described their families as including members in many countries, including Egypt, Germany, France, the UK, and the UAE. Those interviewed referred to their best friends in Iraq and abroad with whom they keep in touch online, which is consistent with the narratives of young Iraqis in the Jordan sample group. Three of those interviewed said that the internet was forbidden in Iraq before 2003, although most had accessed the internet in Iraq because they were there within the last three years.

However, significant differences between these groups can be discerned. Among the 
young Iraqis interviewed in the US, all but one owned a smart phone. They use programs like Whatsapp, Viber, Yahoo Messenger, and Skype from their phones in order to communicate with their family anytime and anywhere. All but one woman, whose family lives in the countryside with no access to the infrastructure that exists in Baghdad, reported regularly using the internet to communicate with family and friends in Iraq. Three participants had internet service in Iraq before 2003, one as early as 1999 . They reported no financial difficulties with their communication method. Their security concerns were significantly less pronounced; most said they had nothing to hide and didn't worry about government surveillance, although two noted that they're very careful about what they post on Facebook because they think that there are still people looking for their name and face. As highly educated individuals, education did not affect any member of this group's ability to access technology.

It seems that the contrast between these groups is less a result of the great differences between the Jordanian and American contexts, but because of the significant socioeconomic status distinctions between the Jordanian and American sample groups. Time spent in Jordan saps Iraqi refugees' funds. Even Iraqis who arrived with large savings are now having financial difficulties because they can't find legal work. SIVs, of which there were many in the US group, come directly from Iraq to the US and so they do not need to remain for a long period of time in a country where they can't work. They are more likely to come to the US with some savings. A smart phone is financially out of reach for most of those interviewed in Jordan, so of course smart phone apps and communication are not significant to this group. Also, while internet communication is a special and valuable luxury for Iraqis in Jordan, it is commonplace and relatively inexpensive for Iraqis in the US sample group. Including more non-SIV Iraqis in the Louisville sample group would make the groups easier and fairer to compare. As it is, the 
comparison between the two groups is limited.

The data collected from this study match Iaria's conclusions. The importance of ICT use to emotional resilience and information networks was observed, as well as the growing role of the internet to serve the same purposes. In addition, the results of this study indicate that Calhoun's hope that Iraqis will use the internet to build community within Jordan may only be fulfilled within the young adult (18-35) community. It seems that efforts to disseminate information and build community using the internet would be most effective for this age group. It doesn't seem that Iraqis in Jordan use ICTs to create new social ties as much as Iraqis in the US do. For the older generation of Iraqis, transnational communication is reserved for relatives, but this seems to be changing for the new generation. It seems that transnational communication, as it is becoming easier, is becoming more relevant for young refugees.

Contrary to Loch et al.'s conclusions, sociocultural factors do not impair access, but they do change the nature of access patterns. Iraqis clearly value the internet and use it in a particularly Arab way - to strengthen family ties and maintain social connections. Despite physical distance, Iraqi refugee families remain affiliated with their extended kin. They live partially in a virtual space that replicates a living arrangement in which multiple generations of a family share a home and/or neighborhood and can visit each other regularly.

Most significantly, this study demonstrates that Iraqi refugees have created transnational social fields and circuits. They are true transmigrants, part of an international community that transgresses borders. Because they cannot safely physically return to Iraq, this phenomenon would not be possible without the communication capabilities that ICTs provide. Extended family members are a constant presence in each others' lives, making decisions, celebrating births and marriages, mourning deaths, and just sharing each others' lived experiences. 
This is a significant addition to knowledge about the phenomenon of transnational ICT use that will hopefully be used by resettlement agencies and aid organizations in the future. They should recognize that ICTs are tools that can help refugees to maintain vital social networks during their transition into a new environment. These connections can ease some of the stress that refugees deal with when they are separated from family and friends. They also help refugees connect with migrants and others who are already in the US to establish new support networks. Additionally, computer and internet literacy are valuable skills that are necessary in the job market and for finding work in the US. Organizations that assist refugees should therefore encourage and empower their clients to utilize ICTs whenever possible. 


\section{Works Cited}

Alahmed, Nina, and Arang Keshavarzian

2010 A War on Multiple Fronts. In Middle East Report. Pp. 17-28, Vol. 40.

al-Zou'bi, Haitham

2012 Lecture on Status of Iraqi and Syrian Refugees in Jordan.

Antoon, Sinan

2010 Bending History. In Middle East Report. Pp. 29-31, Vol. 40.

Baldassar, Loretta, Cora V. Baldock, and Raelene Wilding

2007 Families caring across borders : migration, ageing, and transnational caregiving. New York: Palgrave Macmillan.

Bernal, Victoria

2010 Eritrea Online: Diaspora, cyberspace, and the public sphere. American Ethnologist 32(4):660-675.

Calhoun, Noel

2010 With a Little Help from Our Friends: A Participatory Assessment of Social Capital among Refugees in Jordan. 189. United Nations High Commissioner on Refugees, Policy Development and Evaluation Service.

Coleman, E. Gabriella

2010 Ethnographic Approaches to Digital Media. Annual Review of Anthropology 39:487-505.

Dalen, Kristin, and Jon Pedersen

2010 Iraqis in Jordan Their Number and Characteristics. Fafo.

Flemming, Jennifer 
2011 Making Online Connections. In Forced Migration Review. Pp. 34, Vol. 38. Oxford: Refugee Studies Centre.

Frieden, Terry

20112 Iraqis Arrested in Kentucky, Charged with Aiding Al Qaeda in Iraq. CNN Justice, 31 May 2011.

Garfield, Richard

2000 The Public Health Impact of Sanctions: Contrasting Responses in Iraq and Cuba. In Middle East Report. Pp. 16-19, Vol. 30.

Ghazal, Mohammad

2012 'Vague' Press Law Amendments Would Harm Ict Sector, Experts Warn. The Jordan Times, 4 September 2012.

Glick Schiller, Nina, Linda Basch, and Cristina Szanton Blanc 1995 From Immigrant to Transmigrant: Theorizing Transnational Migration. Anthropology Quarterly 68(1):48-63.

Graham-Brown, Sarah 2000 Sanctioning Iraq: A Failed Policy. In Middle East Report. Pp. 8-13, 35, Vol. 30. Hyndman, Jennifer, and Margaret Walton-Roberts 2000 Interrogating Borders: a transnational approach to refugee research in Vancouver. Canadian Geographer 44(3):244-258.

Iaria, Vanessa

2011 Iraqi Refugees' Informal Information Systems in Syria and Jordan. Bulletin of the Council for British Research in the Levant 6:43-49.

Information \& Communications Technology Association - Jordan 
2011 Jordan Ict Sector Profile: Analysis, Achievements, Aspirations.

Ionita, Daniela

2011 Community Technology Access Project. In Forced Migration Review. Pp. 31-32, Vol. 38 .

Iraq Ministry of Communications

2008 Information Technology \& Communications Use Survey.

Klein, Naomi

2007 The shock doctrine : the rise of disaster capitalism. New York: Metropolitan Books/Henry Holt.

Kukis, Mark

2011 Voices from Iraq : a people's history, 2003-2009. New York: Columbia University Press.

Libal, Kathryn, and Scott Harding 2007 The Politics of Refugee Advocacy and Humanitarian Assistance. In Middle East Report, Vol. 37.

Majeed, Nadeem

2009 Internet Cafe in Baghdad Caters to Women. USA Today, 22 September 2009.

Mearsheimer, John J., and Stephen M. Walt

2007 Iraq and Dreams of Transforming the Middle East. In The Israel lobby and U.S. foreign policy. 1st edition. Pp. 229-262. New York: Farrar, Straus and Giroux.

Panagakos, Anastasia, and Heather Horst

2006 Return to Cyberia: Technology and the Social Worlds of Transnational Migrants. Global Networks 6(2):109-124. 
Peteet, Julie

2007 Unsettling the Categories of Displacement. In Middle East Report, Vol. 37.

Pfanner, Eric

2012 Iraq Emerges from Isolation as Telecommunications Hub. The New York Times, 15 April 2012.

Rouse, Roger

1999 [1995] Mexican Migration and the Social Space of Postmodernism. In Migration, Diasporas, and Transnationalism. S. Vertovec and R. Cohen, eds. Cheltenham, UK:

Edward Elgar Publishing Ltd.

Sassoon, Joseph

2009 Iraqi Refugees in Jordan. In The Iraqi refugees : the new crisis in the Middle East. Pp. 33-60. International library of migration studies, Vol. 3. New York: I.B. Tauris.

Seeley, Nicholas

2010 The Politics of Aid to Iraqi Refugees in Jordan. In Middle East Report, Vol. 40.

Sen, Biswajit

20032003 Irq: Iraq Watching Briefs — Overview Report, July 2003. United Nations Children's Fund.

Shadid, Anthony

2005 Night draws near : Iraq's people in the shadow of America's war. New York: Henry Holt.

The Center for Economic and Social Rights 1996 Unsanctioned Suffering: A Human Rights Assessment of United Nations Sanctions on Iraq. 
Tripp, Charles

2007 A history of Iraq. New York: Cambridge University Press.

United Nations Educational, Scientific, and Cultural Organization (UNESCO)

2003 Unesco and Education in Iraq Fact Sheet.

United Nations High Commissioner for Refugees (UNHCR)

2003a Chronology: 1991 Gulf War Crisis.

2003b Iraqi Refugee and Asylum Seeker Statistics.

20072005 UNHCR Statistical Yearbook.

2008 Iraqi Displacement as of April 2008.

2010 UNHCR Global Report 2010, Jordan.

2010 [1951, 1967] Convention and Protocol Relating to the Status of Refugees.

2011 UNHCR Global Report 2011, Jordan.

2012 UNHCR Global Report 2012, Jordan.

20132013 UNHCR Country Operations Profile - Jordan.

United Nations Security Council, 2933th meeting 
1990 Resolution 661 (1990) [On the situation between Iraq and Kuwait] (S/RES/661). United States Citizenship and Immigration Services

2013 Iraqi Refugee Processing Fact Sheet.

Wheeler, Deborah

2004a Blessings and Curses: Women and the Internet Revolution in the Arab World. In Women and media in the Middle East : power through self-expression. N. Sakr, ed. Library of modern Middle East studies, Vol. 41. New York: I.B. Tauris.

2004b The Internet in the Arab World: Digital Divides and Cultural Connections: Royal Institute for Inter-Faith Studies.

2006 Empowering publics: Information Technology and democratization in the Arab World - Lessons from Internet cafes and beyond. Oxford Internet Institute Research Reports 11:3-18. 


\section{Appendix I}

\section{Interview Questions}

1. What is your age? Where were you born? Where were you raised? What sort of education did you receive?

2. In what year did you leave your home in Iraq? Have you visited since then?

3. Where did you go when you left your home? Who left with you? Who stayed behind?

4. Who do you communicate with in Iraq? Your friends? Your family? How do you usually communicate with them? How often?

5. Who do you communicate with in other countries? Your friends? Your family? How do you usually communicate with them?

6. Who do you communicate with in Jordan? Your friends? Your family? How do you usually communicate with them?

7. While in Iraq, did you have access to the internet? If so, how did you connect? (home, smart phone, library, cafe, etc.) Was it difficult? Was the connection good?

8. While in other countries before you came to Jordan (if applicable), did you have access to the internet? If so, how did you connect? Was it difficult? Was the connection good?

9. Do you have regular access to the internet now? If so, how do you connect? What web sites do you like to visit? What programs do you use? Is it difficult to connect? Is your connection good?

10. If you don't use the internet to communicate with others, why?

11. When you communicate on the internet, what language do you use?

12. What kind of information do you feel safe sharing on the internet? Is the internet safe? Are mobile phones safe? 